\title{
Retrofit measures evaluation considering thermal comfort using building energy simulation: two Lisbon households
}

\author{
Ricardo Gomes $\mathbb{D}^{\mathrm{a}}$, Ana Ferreirab ${ }^{\mathrm{b}}$, Luís Azevedo ${ }^{\mathrm{a}}$, Rui Costa Neto ${ }^{\mathrm{a}}$, Laura Aelenei ${ }^{\mathrm{b}}$ and \\ Carlos Silva ${ }^{a}$
}

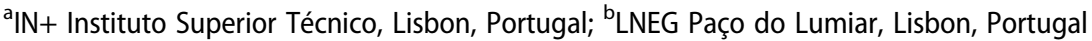

\begin{abstract}
Retrofit measures for buildings are in general evaluated considering the energy savings and life cycle cost. However, one of the main benefits, the increase of users comfort is very seldom analysed. In this work, two residential households representative of a large share of households in Portugal, were monitored and its thermal behavior was modeled using Energy Plus. The thermal evaluation of the pre-retrofit households shows that the winter season is problematic due to construction solutions and low availability for heating. The retrofit measures analysis was performed considering different retrofit solutions regarding envelope improvement and efficient systems implementation. In order to work around the question of comparing households that do not use energy for acclimatization and therefore have very low energy consumption, in the retrofit scenarios it was considered the thermal comfort evaluation value for the real case (pre-retrofit) and compared the energy consumption to achieve that same average comfort level (in this case avoiding high discomfort peaks). The measures that more rapidly pay the investment are those related with implementing active systems. The approach used in this paper, should be used in more calibrated models in order to have overall conclusions about the retrofit process at a larger scale.
\end{abstract}

\section{ARTICLE HISTORY}

Received 30 May 2018

Accepted 11 August 2018

\section{KEYWORDS}

Building energy simulation; thermal comfort; fuel poverty; retrofit measures; building model calibration

\section{Introduction}

In 2010, the European Commission has published an updated version of the Energy Performance of Buildings Directive, which emphasizes the need for 'Energy Efficient Retrofitting' (EER) of existing buildings (Boermans et al., 2015). In general, EER focuses on the implementation of retrofitting measures in an existing building, aiming to reduce the total energy demand, while maintaining, or even improving, the required levels of occupant thermal comfort.

In Portugal - due to a governmental policy of the 1960s to regulate renting prices and that was only abolish in the last decade - the renting prices were artificially maintained at very low values, therefore, the rental revenues were not sufficient for house owners to perform the adequate maintenance of the buildings. This has led to a strong reduction 